\title{
Response of Pecan Orchard Soil Chemical and Biological Quality Indicators to Poultry Litter Application and Clover Cover Crops
}

\author{
M. Lenny Wells \\ Department of Horticulture, University of Georgia, Tifton Campus, 4604 \\ Research Way, Tifton, GA 31793
}

Additional index words. soil microbial biomass, mycorrhizal inoculum potential, phosphatase, organic matter, Carya illinoinensis

\begin{abstract}
Little information is available regarding the activity of soil quality biological indicators in southeastern U.S. pecan [Carya illinoinensis (Wangenh.) K. Koch] orchards. The objectives of this study were to examine the effect of poultry litter application and the use of crimson clover (Trifolium incarnatum $\mathbf{L}$.) as a cool-season cover crop on soil chemistry and soil quality biological indicators, including mycorrhizal inoculum potential (MIP), microbial biomass carbon (MBC), and phosphatase activity in a southeastern U.S. Coastal Plain pecan orchard system. The use of clover as a coolseason cover crop between tree rows provided multiple benefits for pecan orchard soil quality, including increased MIP and MBC. Soil phosphatase activity was also enhanced by clover during two of the three years of study. Soil elemental properties, including total nitrogen $(\mathrm{N})$, and soil organic matter (SOM) were also enhanced by clover and/or poultry litter, although there was an obvious time lag in the response of soil $\mathbf{N}$ to the treatments. Poultry litter application increased soil phosphorus (P) but did not consistently enhance soil biological activity parameters. At times, poultry litter appeared to neutralize or minimize the positive effects of clover on MIP.
\end{abstract}

Pecan is one of the few native North American plant species to have been developed into a significant agricultural crop. Pecans are commercially produced across a wide geographic range in 14 states within the United States, generating a crop valued at \$369 million [U.S. Department of Agriculture (USDA), 2010]. Aside from the United States, pecans are also produced in Mexico, Brazil, Peru, Argentina, Australia, South Africa, Israel, and Egypt. Georgia lies outside the tree's native range but annually produces more pecans than any other state, comprising nearly $30 \%$ of the U.S. pecan crop annually (USDA, 2010).

The bottomland soils on which pecans grow in their native range vary considerably from those on upland sites where the trees are cultivated and grown commercially in the southeastern United States. The loamy bottomland ridges to which pecans are adapted typically consist of well-drained soils high in organic matter (Sparks, 2005). By contrast, upland soils of the southeastern United States

\footnotetext{
Received for publication 3 Nov. 2010. Accepted for publication 1 Dec. 2010.

This work was supported by the Georgia Agricultural Commodity Commission for Pecans.

We thank Del Taylor, Mike Crumley, Mike Hudson, and Cody Casey for technical assistance and to Abid Al-Agely, University of Florida, for assistance with soil microbial analysis.

e-maillwells@uga.edu.
}

are relatively shallow and are comparatively low in organic matter.

Most studies of pecan orchard soils have focused primarily on soil mineral nutrition status and their effects on pecan production. Studies regarding the biological parameters of pecan orchard soils are limited. Biological indicators of soil quality such as microbial biomass and enzyme activity are sensitive to changes in agricultural management practices (Doran et al., 1987). Shading of soil and high detritus inputs in the form of leaf and litter fall may reduce soil temperatures and increase soil moisture in orchard systems. Thus, microbial biomass and nutrient cycling processes are affected by the altered microclimate in orchard and agroforestry systems as compared with forest ecosystems or agroecosystems (Lee and Jose, 2003).

In the early years of the Southeastern pecan industry, legumes and cow manure, provided by cattle grazing the orchards, were commonly used to provide fertilizer $\mathrm{N}$ for pecan trees. After World War II, pecan producers began using synthetic fertilizer on a large scale as a result of the low cost and ease of application (White et al., 1982). As airblast sprayers became available and fungicide and insecticide applications became more routine, grazing cattle in the orchards was discontinued by most growers. Recent instability in fuel and fertilizer prices have led pecan producers to once again consider the use of various legumes such as crimson clover as an orchard floor cover to supplement the pecan tree's $\mathrm{N}$ requirements. In 2005, clover (Trifolium sp.) was used in only $15 \%$ of surveyed pecan orchards in Georgia, but by 2008 , nearly half of all pecan orchards surveyed used clover as an orchard floor cover (Wells, 2009). Smith et al. (1996) suggested that a combination of crimson clover and hairy vetch (Vicia villosa Roth) could be used as a cover crop to meet the $\mathrm{N}$ requirement of pecan.

Early studies of pecan by Blackmon (1936) showed that animal manure can lead to high yields and serve as an excellent source of plant nutrients. Georgia poultry farmers produce over two million tons of poultry litter (manure) annually (Ritz and Merka, 2009) in the production of meat and eggs, creating a need for disposal. Proper application of litter to the land as a soil amendment is an appropriate use for the waste product. The organic material and nutrients found in poultry litter are beneficial byproducts that have proven useful in amending agricultural soils (Mitchell and Tu, 2005).

Doran and Parkin (1994) defined soil quality as "the capacity of a soil to function within ecosystem boundaries to sustain biological productivity, maintain environmental quality, and promote plant and animal health." Soil quality is generally related to the physical, chemical, and biological factors on a particular site. Characterization of soil quality requires the selection of indicators sensitive to changing agricultural practices (Doran et al., 1994). Soil microorganisms are vital to the biogeochemical cycling of organic and inorganic nutrients in the soil and maintenance of soil quality. Microbial activity in the rhizosphere is a major factor that determines the availability of nutrients to plants and has a significant effect on plant health and productivity. Enzymes produced by soil microorganisms and plants mineralize organically bound nutrients and are often used as indicators of soil quality (Doran and Parkin, 1994).

Mycorrhizal relationships are often considered the most significant form of plantmicrobe symbiosis (Smith and Read, 1997). Ectomychorrhizal fungi form a particular, extracellular morphological complex with the roots of many temperate forest trees, including pecan (Woodruff, 1933). However, the arbuscular mycorrhizal (AM) fungi form the most widespread symbiotic relationship between plants and fungi in nature. Over $80 \%$ of plant species can form AM. The extensive hyphal network created by AM can improve soil aggregation (Miller and Jastrow, 1992). Organic compounds produced by mycorrhizal hyphae may bind soil microaggregates into macroaggregates (Tisdall, 1994). Mycorrhizae have been shown to favor soil conditions of high organic matter and low fertility (Miller and Jastrow, 1992).

Research on mycorrhizal relationships in pecan are limited. Woodruff (1933) described several forms of ectomycorrhizae on pecan roots in Georgia. Marx and Bryan (1969) found that Scleroderma bovista formed ectomychorrhizae on pecan roots and inhibited pathogenic fungi associated with feeder-root 
necrosis of pecan. Sharpe and Marx (1986) demonstrated enhanced growth and mineral nutrient content of pecan seedlings by inoculation of trees with Pisolithus tinctorius ectomycorrhizae. Arbuscular mychorrhizae have not been documented from pecan roots; however, both ectomycorrhizae and AM occur in southeastern U.S. pecan orchards and thrive under similar conditions (Hayman, 1982; Mader et al., 2000; Marx and Bryan, 1969; Woodruff, 1933).

Soil amendment with organic materials such as poultry litter and/or legumes such as clover should improve southeastern U.S. pecan orchard soils, thus enhancing their sustainability. There are few studies regarding the activity of soil quality biological indicators in pecan orchards and none examining the effects of clover and poultry litter on soil quality biological indicators in southeastern U.S. pecan orchards. Therefore, the purpose of this study was to examine the effect of poultry litter application and the use of crimson clover as a cool-season cover crop on soil chemistry and soil quality biological indicators, including MIP, MBC, and phosphatase activity in a southeastern U.S. Coastal Plain pecan orchard system.

\section{Materials and Methods}

Study site, experimental design, soil sampling. The study was conducted in a 25 -yearold solid-set sprinkler-irrigated pecan orchard on $12.2 \times 12.2-\mathrm{m}$ spacing located at the University of Georgia Tifton Campus Ponder Research Farm near Tifton, GA, from 2008 to 2010. Soil type was Fuquay loamy sand (loamy, siliceous, thermic Arenic Plinthic Paleudult). The orchard was managed under commercial conditions according to University of Georgia Cooperative Extension recommendations (Hudson et al., 2010). A 3.7-m wide herbicide strip was maintained with glyphosate along the tree row in all plots. Row middles consisted of bermudagrass (Cynodon dactylon L.) sod only except where indicated subsequently. The following treatments were evaluated: 1) crimson clover; 2) poultry litter; 3) crimson clover + poultry litter; and 4) ammonium nitrate. An untreated control was added to the treatments beginning in 2009. Treatments were arranged in a randomized block design using six replications. Each plot consisted of a $24.4 \mathrm{~m} \times 24.4 \mathrm{~m}$ area centered on an individual pecan tree. All plots were separated by untreated border plots.

Crimson clover was broadcast-seeded annually over the bermudagrass sodded row middles beginning in Oct. 2007 at a rate of $33.6 \mathrm{~kg} \cdot \mathrm{ha}^{-1}$ to ensure a full stand in the crimson clover and crimson clover + poultry litter plots. Poultry litter was applied at a rate of $2240 \mathrm{~kg} \cdot \mathrm{ha}^{-1}$ on $31 \mathrm{Mar}$. 2008, $31 \mathrm{Mar}$. 2009, and 29 Mar. 2010. Poultry litter analysis for each year of study can be found in Table 1. Ammonium nitrate (34-0-0) was applied at a rate of $84 \mathrm{~kg} \mathrm{~N} / \mathrm{ha}$ on 31 Mar. 2008, 31 Mar. 2009, and 29 Mar. 2010. Zinc sulfate $\left(62.9 \mathrm{~kg} \cdot \mathrm{ha}^{-1}\right)$ and muriate of potash $\left(70.6 \mathrm{~kg} \cdot \mathrm{ha}^{-1}\right)$ were applied to all plots on 23

Table 1. Mineral analysis of poultry litter used during 2008, 2009, and 2010 study. ${ }^{\mathrm{z}}$

\begin{tabular}{rrrrrrrrrrrr}
\hline & $\mathrm{N}$ & $\mathrm{P}$ & $\mathrm{K}$ & $\mathrm{Ca}$ & $\mathrm{Mg}$ & $\mathrm{S}$ & $\mathrm{Mn}$ & $\mathrm{Fe}$ & $\mathrm{B}$ & $\mathrm{Cu}$ & $\mathrm{Zn}$ \\
\cline { 2 - 11 } & & \multicolumn{10}{c}{$\left(\mathrm{kg} \cdot \mathrm{t}^{-1}\right)$} \\
2008 & 34 & 7 & 14 & 14 & 3 & 3 & 0.2 & 0.5 & 0.01 & 0.2 & 0.2 \\
2009 & 28 & 28 & 31 & 22 & 5 & 5 & 0.2 & 2 & 0.03 & 0.4 & 0.3 \\
2010 & 27 & 27 & 30 & 20 & 5 & 5 & 0.2 & 2 & 0.02 & 0.4 & 0.3 \\
\hline
\end{tabular}

${ }^{\mathrm{z}}$ Measured nutrients were nitrogen $(\mathrm{N})$, phosphorous $(\mathrm{P})$, potassium $(\mathrm{K})$, magnesium $(\mathrm{Mg})$, calcium $(\mathrm{Ca})$, sulfur $(\mathrm{S})$, manganese $(\mathrm{Mn})$, iron $(\mathrm{Fe})$, boron $(\mathrm{B})$, copper $(\mathrm{Cu})$, and zinc $(\mathrm{Zn})$.

Mar. 2009. Plots with clover or poultry litter did not receive $\mathrm{N}$ from other fertilizer sources.

Soil biological activity samples were collected from each plot annually during the last week of June. Six $4.45-\mathrm{cm}$ soil cores at $15.2-\mathrm{cm}$ depth were collected from each plot beneath the tree canopy and outside the herbicide strip on each side of the tree. Samples were combined into one composite sample per plot and placed in a plastic bag in a cooler for transport from the field. All samples were refrigerated until analysis.

Estimation of mycorrhizal inoculum potential. Mycorrhizal inoculum potential was measured using a bioassay with sweet corn (Zea mays L.) as the host plant (Schenck, 1982; Sylvia, 1994). Ten grams of soil inoculum from test plots were added to culture media in 4-cm diameter containers, gently mixed, and covered with $3 \mathrm{~cm}$ of additional culture media. Three seeds of sweet corn (cv. Silver Queen) were planted to each container. Containers were placed into a growth chamber, fertilized with Hoagland's Solution of $0.01 \mathrm{M}$ phosphorus weekly, and irrigated as needed. After $28 \mathrm{~d}, 0.5$-g root samples were harvested from each plant and placed in a beaker with $10 \% \mathrm{KOH}$. Roots were heated to $90{ }^{\circ} \mathrm{C}$ for 10 to $15 \mathrm{~min}$ and rinsed with distilled water. Roots were then placed in $0.1 \mathrm{~N} \mathrm{HCl}$ for $5 \mathrm{~min}$ and drained. Root samples were stained with trypan blue-lactic acid and heated for $10 \mathrm{~min}$ at $90{ }^{\circ} \mathrm{C}$ before rinsing twice. Root colonization was estimated by placing stained roots in a petri dish with a $1.27-\mathrm{cm}$ grid on the outside bottom half of the dish. Root segment intersections with the gridlines were recorded for those root segments with and without AM fungi using $2 \times$ magnification. Percent colonization was estimated by dividing the number of root intersections with the grid colonized by AM by the total number of root intersections (Koide and Mooney, 1987). Three subsamples from each plot were assayed.

Microbial biomass carbon estimates. Soil microbial biomass carbon (C) estimates were made in 2009 and 2010 using microwave irradiation (Hendricks and Pascoe, 1988; Islam and Weil, 1998). Two 10-g soil sample replicates from each plot were dried to $10 \%$ moisture, placed in a $50-\mathrm{mL}$ vial, and microwaved at high power for $10 \mathrm{~s}$ with a $700-\mathrm{W}$, 2450-MHz microwave. One milliliter of $1 \mathrm{~N}$ $\mathrm{NaOH}$ was added to the vial, which was then sealed with a rubber stopper. Samples were then incubated for $10 \mathrm{~d}$. After incubation, samples were titrated with $1 \mathrm{~N} \mathrm{HCl}$. Biomass $\mathrm{C}$ evolved from soils was calculated using the formula: $\mathrm{C}$ biomass $=(\mathrm{B}-\mathrm{V}) \mathrm{NE}$, where $\mathrm{B}=$ volume of acid to titrate alkali from controls (non-microwaved soil) to the end point, $\mathrm{V}=$ volume $(\mathrm{mL})$ of acid to titrate the alkali from microwaved soil, $\mathrm{N}=$ normality of the acid, and $\mathrm{E}=$ equivalent weight. Carbon biomass is based on the assumption that $\mathrm{C}$ comprises $50 \%$ of living cell dry matter.

Phosphatase activity. Phosphatase activity was estimated using p-nitrophenyl phosphate as a substrate (Dick and Tabatabai, 1992). Approximately $1 \mathrm{~mL}$ distilled $\mathrm{H}_{2} \mathrm{O}$ was added to $0.25 \mathrm{~g}$ of soil in an aluminum foil-covered microcentrifuge tube and swirled gently. The reaction was initiated by addition of $0.25 \mathrm{~mL}$ of $100 \mathrm{~mm}$ p-nitrophenyl phosphate to treatment tubes. Samples were incubated in centrifuge at $175 \mathrm{rpm}$ for $30 \mathrm{~min}$. The reaction was ended by addition of 0.25 $\mathrm{mL}$ of each $0.5 \mathrm{M} \mathrm{CaCl} 2$ and $0.5 \mathrm{M} \mathrm{NaOH}$. Tubes were then centrifuged at $10,000 \mathrm{rpm}$ for $10 \mathrm{~min}$. Levels of p-nitrophenyl phosphate were measured using a microplate reader (BIO RAD Model 550; Bio Rad Laboratories, Hercules, CA) programmed to calculate the concentration of p-nitrophenol based on a standard curve of 0 to $10 \mu \mathrm{M}$ of p-nitrophenol.

Orchard soil mineral analysis. Six soil cores per plot from 0 - to $15-\mathrm{cm}$ depth were combined as one composite soil sample taken from under the drip line of trees. Soil was dried and analyzed for elemental P, total N, and SOM. Cation exchange capacity was analyzed in 2009 and 2010. The Mehlich-1 method was used to extract soil P. Soil P was determined by inductively coupled plasma. Soil organic matter was determined by the loss on ignition method and is expressed as percent by weight. Total soil $\mathrm{N}$ was analyzed by combustion, converting $\mathrm{N}$ to $\mathrm{N}_{2}$. The gases were then passed through a thermal conductivity cell to determine $\mathrm{N}$ content (Kissell and Sonon, 2008).

Data analysis. Statistical analyses of data were performed with SAS (SAS Institute, 1990). Analysis of variance was used to compare treatment effects. Means were separated using Duncan's multiple range test $(P \leq 0.05)$.

\section{Results and Discussion}

There was no difference in total soil $\mathrm{N}$ between treatments during the first two years of study; however, in 2010, the percentage of total soil $\mathrm{N}$ was higher in the clover treatment than in the untreated control (Table 2). Thus, clover grown in row middles enhanced orchard soil N; however, this effect was only observed after multiple years of management for clover, indicating a potential time lag in the buildup of $\mathrm{N}$ in orchard soils after the change in management (Table 2). Smith et al. 
(1996) reported an increase in pecan orchard soil Kjeldahl-N and soil nitrate $\left(\mathrm{NO}_{3}\right)-\mathrm{N}$ with clover used as a cool-season cover crop. A study of apple (Malus $\times$ domestica Borkh.) orchards by Hoagland et al. (2008) reported greater total $\mathrm{N}$ in soil using a living legume mulch than in those without. In the current study, all plots had some form of vegetation between tree rows, whether in the form of bermudagrass or bermudagrass overseeded with clover as a cool-season cover crop. Total soil $\mathrm{N}$ would be expected to respond slowly to variations in agricultural management, particularly in a non-tilled system such as a pecan orchard, in which soil amendments, including plant residue, are left on the soil surface after mowing. There were no treatment differences in $\mathrm{C}: \mathrm{N}$ ratio during the course of the study (data not shown).

Soil organic matter was $20 \%$ and $22 \%$ higher $(P<0.05)$ in the clover + litter and poultry litter treatments, respectively, than in the ammonium nitrate treatment during 2008 (Table 2). In 2009 , SOM was $21 \%$ higher $(P$ $<0.05)$ in both the clover and litter treatments than in the untreated control. Additionally, SOM was $13 \%$ higher in the ammonium nitrate treatment than in the untreated control. Clover + litter and clover alone increased $(P<0.05)$ SOM by $46 \%$ and $34 \%$, respectively, over the untreated control in 2010. These results indicate that organic soil amendments such as clover and poultry litter can enhance SOM of orchard soils over grass sod middles. Ammonium nitrate also enhanced SOM during one year of study; however, this effect was not as consistent as that seen with poultry litter and/or clover. Wells (2009) previously reported an increase in SOM for orchards using clover as a coolseason orchard floor covering compared with those orchards using only sod. In the current study, there was a considerable amount of variation in SOM from one year to the next. This may be the result of an error in sampling depth of the soil core in the final year of study. Despite the fluctuation in SOM values between years, the clover and poultry litter treatments consistently increased SOM. Cation exchange capacity was unaffected by treatments (data not shown).

As expected, soil $\mathrm{P}$ was highest $(P \leq$ $0.05)$ in the poultry litter and clover + litter treatment during each year of study (Table 1). This is the result of the relatively high levels of $\mathrm{P}$ input that come with poultry litter application as has been reported for previous studies (Daniel et al., 1998; Mitchell and Tu, 2006; Novak et al., 2002). Soil P levels were found to be adequate for pecan production in all other plots; therefore, no additional $\mathrm{P}$ was applied in the other treatments.

Mycorrhizal inoculum potential declined in all treatments throughout the course of the study. This decline may be partly explained by the routine use of fungicides applied to the trees in the orchard for control of pecan scab. The study orchard had received occasional fungicide applications before the study; however, a more strict fungicide program was implemented with the beginning of the study.
Several fungicides have been previously reported to be detrimental to AM symbiosis (Schreiner and Bethlenfalvay, 1997). Residues from the application of fungicides to trees may have accumulated in the orchard soil; however, soil fungicide residues were not measured. It is also possible that there was a sampling error either in the field or laboratory that caused the low MIP in 2010.

During each year of study, MIP was higher $(P \leq 0.05)$ in the clover treatment than in all other treatments (Table 3 ). These results support previous studies that reported increased MIP with the growth of mycotrophic winter cover crops (Boswell et al., 1998). Kabir and Koide (2000) found that a living vegetative cover of dandelion (Taraxacum officinale Weber) during the winter improved MIP and soil aggregation. Burggraaf and Beringer (1989) have suggested that as a result of the long coevolution of the AM symbiosis, the host plant may have complete control over the fungal life cycle. Because MIP was reduced in the control treatment relative to the clover treatment, it is evident that clover enhanced MIP.

Mycorrhizae are generally higher in soils with high organic matter but may be reduced under conditions of increased soil fertility

(Miller and Jastrow, 1992). The difference found in MIP between treatments in the current study partly reflected the intensity of fertilizer input and soluble nutrient content, especially of $\mathrm{P}$, in the soils of the plots receiving poultry litter or ammonium nitrate. This was in agreement with previous studies that showed $\mathrm{P}$ to have a pronounced effect on the development of AM symbiosis with the percentage of AM root colonization decreasing as the P status of the host plant increased (Hayman, 1982; Mader et al., 2000; Smith and Read, 1997). Although MIP was heavily influenced by the presence of crimson clover in the current study, neither the application of ammonium nitrate nor poultry litter enhanced MIP, even in the presence of clover, indicating that $\mathrm{N}$ fertilization may have also decreased mycorrhizal activity, which is consistent with many studies (Bentivenga and Hetrick, 1992; Ellis et al., 1992; Grogan and Chapin, 2000).

Several studies have reported higher MBC from farming systems receiving higher amounts of organic inputs than from those with conventional inputs (Bossio et al., 1998; Gunapala and Scow, 1998). MBC was not measured in the first year of the current study, but in 2009, MBC was higher $(P \leq 0.05)$ in all plots with clover and/or poultry litter than in the control or

Table 2. Total soil nitrogen $(\mathrm{N})$, soil organic matter (SOM), and soil phosphorus $(\mathrm{P})$ for clover, poultry litter, clover + poultry litter, ammonium nitrate, and control treatments from 2008-2010.

\begin{tabular}{|c|c|c|c|c|}
\hline $\mathrm{Yr}$ & Treatment & $\mathrm{N}(\%)$ & SOM $(\%)$ & $\mathrm{P}\left(\mathrm{kg} \cdot \mathrm{ha}^{-1}\right)$ \\
\hline \multirow{4}{*}{2008} & Clover & $0.10 \mathrm{a}^{\mathrm{z}}$ & $2.65 \mathrm{a}$ & $63 \mathrm{c}$ \\
\hline & Litter & $0.10 \mathrm{a}$ & $2.75 \mathrm{a}$ & $249 \mathrm{a}$ \\
\hline & Clover + litter & $0.10 \mathrm{a}$ & $2.70 \mathrm{a}$ & $152 \mathrm{~b}$ \\
\hline & Ammonium nitrate & $0.10 \mathrm{a}$ & $2.25 \mathrm{~b}$ & $78 \mathrm{c}$ \\
\hline \multirow[t]{5}{*}{2009} & Clover & $0.12 \mathrm{a}$ & $2.44 \mathrm{a}$ & $49 \mathrm{~b}$ \\
\hline & Litter & $0.14 \mathrm{a}$ & $2.44 \mathrm{a}$ & $116 \mathrm{a}$ \\
\hline & Clover + litter & $0.14 \mathrm{a}$ & $2.15 \mathrm{ab}$ & $132 \mathrm{a}$ \\
\hline & Ammonium nitrate & $0.13 \mathrm{a}$ & $2.28 \mathrm{a}$ & $69 \mathrm{~b}$ \\
\hline & Control & $0.13 \mathrm{a}$ & $2.01 \mathrm{~b}$ & $74 \mathrm{~b}$ \\
\hline \multirow[t]{5}{*}{2010} & Clover & $0.14 \mathrm{a}$ & $1.93 \mathrm{a}$ & $63 \mathrm{~b}$ \\
\hline & Litter & $0.11 \mathrm{ab}$ & $1.78 \mathrm{ab}$ & $242 \mathrm{a}$ \\
\hline & Clover + litter & $0.11 \mathrm{ab}$ & $2.10 \mathrm{a}$ & $202 \mathrm{a}$ \\
\hline & Ammonium nitrate & $0.10 \mathrm{ab}$ & $1.74 \mathrm{ab}$ & $92 \mathrm{~b}$ \\
\hline & Control & $0.09 \mathrm{~b}$ & $1.44 \mathrm{~b}$ & $99 \mathrm{~b}$ \\
\hline
\end{tabular}

${ }^{\mathrm{z}}$ Means followed by the same letter are not different at $P \leq 0.05$ by Duncan's multiple range test.

Table 3. Mycorrhizal inoculum potential (MIP), microbial biomass carbon (MBC), and phosphatase activity for clover, poultry litter, clover + poultry litter, ammonium nitrate, and control treatments.

\begin{tabular}{llccc}
\hline Yr & \multicolumn{1}{c}{ Treatment } & $\begin{array}{c}\text { MIP (percent AM } \\
\text { root colonization) }\end{array}$ & $\begin{array}{c}\text { Microbial biomass carbon } \\
(\mathrm{Mg} \mathrm{C} / \mathrm{kg} \text { soil })\end{array}$ & $\begin{array}{c}\text { Phosphatase } \\
\left(\mathrm{mMol}^{-2} \cdot \mathrm{h}^{-1}\right)\end{array}$ \\
\hline 2008 & Clover & $46.7 \mathrm{a}^{\mathrm{z}}$ & - & $10.6 \mathrm{a}$ \\
& Clover/litter & $22.0 \mathrm{~b}$ & - & $9.8 \mathrm{ab}$ \\
& Litter & $26.5 \mathrm{ab}$ & - & $7.5 \mathrm{~b}$ \\
& Ammonium nitrate & $25.9 \mathrm{ab}$ & - & $3.4 \mathrm{~b}$ \\
2009 & Clover & $13.3 \mathrm{a}$ & $250 \mathrm{a}$ & $3.5 \mathrm{a}$ \\
& Clover/litter & $6.7 \mathrm{ab}$ & $220 \mathrm{a}$ & $3.2 \mathrm{ab}$ \\
& Litter & $3.0 \mathrm{~b}$ & $240 \mathrm{a}$ & $2.8 \mathrm{bc}$ \\
& Ammonium nitrate & $4.3 \mathrm{~b}$ & $180 \mathrm{~b}$ & $2.9 \mathrm{abc}$ \\
& Control & $4.4 \mathrm{~b}$ & $170 \mathrm{~b}$ & $2.3 \mathrm{c}$ \\
& Clover & $4.0 \mathrm{a}$ & $140 \mathrm{a}$ & $9.6 \mathrm{a}$ \\
& Clover/litter & $0.0 \mathrm{~b}$ & $120 \mathrm{~b}$ & $8.6 \mathrm{a}$ \\
& Litter & $0.0 \mathrm{~b}$ & $100 \mathrm{~b}$ & $10.4 \mathrm{a}$ \\
& Ammonium nitrate & $0.0 \mathrm{~b}$ & $120 \mathrm{~b}$ & $10.5 \mathrm{a}$ \\
& Control & $0.0 \mathrm{~b}$ & $120 \mathrm{~b}$ & $13.3 \mathrm{a}$ \\
\hline
\end{tabular}

${ }^{z}$ Means followed by the same letter are not different at $P \leq 0.05$ by Duncan's multiple range test.

$\mathrm{AM}=$ arbuscular mycorrhizal. 
synthetic fertilizer treatments (Table 3 ). In 2010, the clover treatment had higher $(P \leq$ $0.05) \mathrm{MBC}$ than all other treatments (Table 3). These results partially support those of Lundquist et al. (1999) who reported an increase in $\mathrm{MBC}$ with vetch and/or poultry litter compared with synthetic fertilizer as a fertilizer source. Weil and Kroontje (1979) also report that the application of organic $\mathrm{C}$ in the form of poultry manure enhanced soil microbial activity compared with synthetic fertilizer use. Although poultry litter appeared to enhance $\mathrm{MBC}$ in one year of the current study, the use of clover as a cool-season cover crop in the orchard appeared to exert the greatest influence on MBC. This supports the results of Angers (1992) and Doran et al. (1987) who found that the type of crop grown often exerts a greater influence on soil biological activity than do agricultural management practices. The growth of clover and the subsequent clover left on the orchard floor in the current study provided a readily assimilable $\mathrm{C}$ source, which could have led to an increase in soil microbial activity.

Soil phosphatase activity was enhanced by the clover treatment in two of the three years of study. Phosphatase activity was $41 \%$ and $43 \%$ higher $(P<0.05)$ in the clover treatment compared with the poultry litter and fertilizer treatments, respectively, during the first year of study (Table 3). In 2009, phosphatase activity was $25 \%$ and $52 \%$ higher $(P<0.05)$ in the clover treatment than in the poultry litter and control treatments, respectively (Table 3). The 2008 and 2009, results can be easily explained by the addition of organic matter in the form of clover plant residue along with the presence of clover roots and the lower soil $\mathrm{P}$ in the clover treatment (Table 2) compared with the other treatments. Phosphatase activity in soil is primarily the result of extracellular enzymes bound to soil particles and dead microbial cells. As previously mentioned, the addition of plant residues, primarily as a $\mathrm{C}$ source, enhances the microbial population, which may in turn increase phosphatase activity (Spiers and McGill, 1979). The presence of a negative relationship between soil $\mathrm{P}$ and phosphatase has been previously observed in many studies (Juma and Tabatabai, 1978; Spiers and McGill, 1979). In the final year of study, there was no difference in phosphatase activity between treatments (Table 3 ). The lack of response of phosphatase activity to treatments in 2010 is puzzling because MBC and soil $\mathrm{P}$, both of which correlate well with soil phosphatase activity, did exhibit a treatment response in the final year. This may be a result of sampling error in the final year of study.

In summary, the use of clover as a coolseason cover crop between tree rows appears to provide multiple benefits for pecan orchard soil quality, including increased MIP and MBC. Soil phosphatase activity was also enhanced by clover during two of the three years of study. Soil elemental properties, including total $\mathrm{N}$ and SOM, were also enhanced by clover and/or poultry litter, although there was an obvious time lag in the response of total soil $\mathrm{N}$ to the treatments. Poultry litter application also enhanced soil $\mathrm{P}$ but did not consistently enhance the soil biological activity parameters examined in this study. At times, poultry litter appeared to neutralize or minimize the positive effects of clover on MIP. The biological and chemical soil quality indicators mentioned provide a practical measurement of pecan orchard soil quality. This study underscores the value of clover as a cool-season orchard floor cover and its potential benefits for soil conservation, soil quality improvement, and sustainability in southeastern U.S. pecan orchards.

\section{Literature Cited}

Angers, D.A. 1992. Changes in soil aggregation and organic carbon under corn and alfalfa. Soil Sci. Soc. Amer. J. 56:1244-1249.

Bentivenga, S.P. and B.A.D. Hetrick. 1992. The effect of prairie management practices on mycorrhizal symbiosis. Mycologia 84:522527.

Blackmon, G.H. 1936. Effects of fertilizer son the yield of pecan trees. Proc. Southeastern Pecan Growers Assn. 30:19-25.

Bossio, D.A., K.M. Scow, N. Gunapala, and K.J. Graham. 1998. Determinants of soil microbial communities: Effects of management, season, and soil type on phospholipid fatty acid profiles. Microb. Ecol. 36:1-12.

Boswell, E.P., R.T. Koide, D.L. Shumway, and H.D. Addy. 1998. Winter wheat cover cropping, VA mycorrhizal fungi, and maize growth and yield. Agr. Ecosyst. Environ. 67:55-65.

Burggraaf, A.J.P. and J.E. Beringer. 1989. Absence of nuclear DNA synthesis in vesicular-arbuscular mycorrhizal fungi during in vitro development. New Phytol. 111:25-33.

Daniel, T.C., A.N. Sharpley, and J.L. Lemunyon. 1998. Agricultural phosphorus and eutrophication: A symposium overview. J. Environ. Qual. 27:251-257.

Dick, W.A. and M.A. Tabatabai. 1992. Significance and potential use of soil enzymes, p. 95130. In: Metting, F.B. (ed.). Soil microbial ecology. Marcel Dekker, New York, NY.

Doran, J.W., D.G. Fraser, M.N. Culik, and W.C. Liebbardt. 1987. Influence of alternative and conventional agricultural management on soil microbial processes and nitrogen availability. Amer. J. Altern. Agr. 2:99-106.

Doran, J.W. and T.B. Parkin. 1994. Defining and assessing soil quality, p. 3-21. In: Doran, J.W., D.C. Coleman, D.F. Bezdicek, and B.A. Stewart (eds.). Defining soil quality for a sustainable environment. SSSA Spec. Publ. 35. SSSA, Madison, WI.

Doran, J.W., M. Sarrantonio, and R. Janke. 1994. Strategies to promote soil quality and soil health, p. 230-237. In: Pankhurst, C.E., B.M. Doube, V.V.S.R. Gupta, and P.R. Grace (eds.) Soil biota: Management in sustainable farming systems. CSIRO, Victoria, Australia.

Ellis, J.R., W. Roder, and S.C. Mason. 1992. Grain sorghum soybean rotation and fertilization influence on vesicular arbuscular mycorrhizal fungi. Soil Sci. Soc. Amer. J. 56:789-794.

Grogan, P. and F.S. Chapin. 2000. Nitrogen limitation of production in a Californian annual grassland: The contribution of arbuscular mycorrhizae. Biogeochemistry 49:37-51.

Gunapala, N. and K.M. Scow. 1998. Dynamics of soil microbial biomass and activity in conventional and organic farming systems. Soil Biol. Biochem. 30:805-816.
Hayman, D.S. 1982. Influence of soil and fertility on activity and survival of vesicular arbuscular mycorrhizal fungi. Phytopathology 72:11191125.

Hendricks, C.W. and N. Pascoe. 1988. Soil microbial biomass estimates using $2450 \mathrm{MHz}$ microwave irradiation. Plant Soil 110:39-47.

Hoagland, L., L. Carpenter-Boggs, D. Granatstein, M. Mazzola, J. Smith, F. Peryea, and J.P. Reganold. 2008. Orchard floor management effects on nitrogen fertility and soil biological activity in a newly established organic apple orchard. Biol. Fertil. Soils 45:11-18.

Hudson, W., J. Brock, S. Culpepper, and L. Wells., 2010. Georgia pecan pest management guide. Univ. Georgia Coop. Ext. Bull. 841.

Islam, K.R. and R.R. Weil. 1998. Microwave irradiation of soil for routine measurement of microbial biomass carbon. Biol. Fertil. Soils 27: $408-416$.

Juma, N.G. and M.A. Tabatabai. 1978. Distribution of phosphomonoesterases in soils. Soil Sci. 126: 101-108.

Kabir, Z. and R.T. Koide. 2000. The effect of dandelion or a cover crop on mycorrhiza inoculum potential, soil aggregation, and yield of maize. Agr. Ecosyst. Environ. 78:167-174.

Kissell, D.E., and L. Sonon. 2008. Soil test handbook for Georgia. Univ. of Ga. Coop. Ext. Special Bul. 62.

Koide, R.T. and H.A. Mooney. 1987. Spatial variation in inoculum potential of vesicular arbuscular mycorrhizal fungi caused by formation of gopher mounds. New Phytol. 107:173-182.

Lee, K.H. and S. Jose. 2003. Soil respiration and microbial biomass in a pecan-cotton alley cropping system in southern USA. Agrofor. Syst. 58:45-54.

Lundquist, E.J., K.M. Scow, L.E. Jackson, S.L. Uesugi, and C.R. Johnson. 1999. Rapid response of soil microbial communities from conventional, low input, and organic farming systems to a wet/dry cycle. Soil Biol. Biochem. 31:1661-1675.

Mader, P., S. Edenhofer, T. Boller, A. Wiemken, and U. Niggli. 2000. Arbuscular mycorrhizae in a long term field trial comparing low input and high input farming systems in a crop rotation. Biol. Fertil. Soils 31:150-156.

Marx, D.H. and W.C. Bryan. 1969. Scleroderma bovista, an ectotrophic mycorrhizal fungus of pecan. Phytopathology 59:1128-1132.

Miller, R.M. and J.D. Jastrow. 1992. The role of mycorrhizal fungi in soil conservation, p. 2944. In: Behtlenfalvay, G.J. and R.G. Linderman (eds.). Mycorrhizae in sustainable agricultrue. ASA Special Publication 54. Amer. Soc. Agron., Madison, WI.

Mitchell, C.C. and S. Tu. 2005. Long term evaluation of poultry litter as a source of nitrogen for cotton and corn. Agron. J. 97:399-407.

Mitchell, C.C. and S. Tu. 2006. Nutrient accumulation and movement from poultry litter. Soil Sci. Soc. Amer. J. 70:2146-2153.

Novak, J.M., P.G. Hunt, K.C. Stone, D.W. Watts, and M.H. Johnson. 2002. Riparian zone impact on phosphorus movement to a Coastal Plain blackwater stream. J. Soil Water Conserv. 57: 127-133.

Ritz, C.W. and W.C. Merka. 2009. Maximizing poultry litter manure use through nutrient management planning. Univ. Ga. Coop. Ext. Bul. 1245.

SAS Institute. 1990. SAS user's guide: Statistics. Vol. 2, 6th Ed. SAS Institute, Cary, NC.

Schenck, N.C. (ed.). 1982. Methods and principles of mycorrhizal research. Amer. Phytopath Soc., St. Paul, MN. 
Schreiner, R.P. and G.J. Bethlenfalvay. 1997. Mycorrhizae, biocides, and biocontrol 3. Effects of three different fungicides on developmental stages of three AM fungi. Biol. Fertil. Soils 24:18-26.

Sharpe, R.R. and D.H. Marx. 1986. Influence of soil $\mathrm{pH}$ and Pisolithus tinctorus ectomycorrhizae on growth and nutrient uptake of pecan seedlings. HortScience 21:1388-1390.

Smith, M.W., A. Shiferaw, and N.R. Rice. 1996. Legume cover crops as a nitrogen source for pecan. J. Plant Nutr. 19:1117-1130.

Smith, S.E. and D.J. Read. 1997. Mycorrhizal symbiosis. 2nd Ed. Academic Press, London, UK.

Sparks, D. 2005. Adaptability of pecan as a species. HortScience 40:1175-1189.
Spiers, G.A. and W.B. McGill. 1979. Effects of phosphorus addition and energy supply on acid phosphatase production and activity in soils. Soil Biol. Biochem. 11:3-8.

Sylvia, D.M. 1994. Vesicular-arbuscular mycorrhizal fungi, p. 351-378. In: Weaver, R.W., S. Angle, and P. Bottomley (eds.). Methods of soil analysis, part 2. Microbiological and biochemical properties. Soil Science Dosciety Amer., Madison, WI.

Tisdall, J.M. 1994. Possible role of soil microorganisms in aggregation in soils. Plant Soil 159: 115-121.

U.S. Department of Agriculture. 2010. Noncitrus fruits and nuts: 2009 summary. Natl. Agr. Stat. Serv., U.S. Dept. Agr, Washington, DC.
Weil, R. and W. Kroontje. 1979. Organic matter decomposition in a soil heavily amended with poultry manure. J. Environ. Qual. 8:584588.

Wells, M.L. 2009. Pecan nutrient element status and orchard soil fertility in the southeastern United States coastal plain. HortTechnology 19:432-438.

White, A.W., E.R. Beaty, and W.L. Tedders. 1982. Legumes as a source of nitrogen and effects of management practices on legumes in pecan orchards. Proc. Southeastern Pecan Growers Assn. 74:97-106.

Woodruff, N.C. 1933. Pecan mycorrhizae. Ga. Exp. Sta. Bul. 178 